\title{
STRATEGI PENINGKATAN KUALITAS PELAYANAN PADA PT SAFINA ASSALAM TOUR GAMBUT KALIMANTAN SELATAN
}

\author{
Achmad Yasin \\ PT Safina Assalam Tour \\ JL A. Yani, Km. 11,8, Gambut, Kabupaten Banjar \\ e-mail : Achmadyasin@ymail.com
}

\begin{abstract}
The aims of this study were to determine the service quality level and to the strategy of PT Safina Assalam Tour to improve service quality. This study was descriptive research. The sampling method was non-probability sampling. The numbers of samples were 50 respondents. The results of this research showed that the service quality level was good, however there were several factors that need to improve, i.e., reliability and communication factors, especially at the document speed processing and handling customers complaints.
\end{abstract}

Keywords: service quality, strategy

Abstrak: Tujuan penelitian ini adalah untuk mengetahui tingkat kualitas pelayanan dan strategi PT Safina Assalam Tour untuk meningkatkan kualitas pelayanan. Penelitian ini adalah penelitian deskriptif. Metode penyampelan dilakukan dengan teknik penyampelan non-probabilitas. Sampel berjumlah 50 responden. Hasil penelitian menunjukkan bahwa kualitas pelayanan sudah baik, namun ada beberapa faktor yang harus diperbaiki pada faktor keandalan dan faktor komunikasi, khususnya pada kecepatan dalam pengurusan dokumen dan menghadapi keluhan pelanggan dengan baik.

Kata Kunci: strategi, kualitas pelayanan

\section{Latar Belakang}

Proses penyelenggaraan haji senantiasa tetap berjalan secara rutin setiap tahunnya, bagaimanapun situasi kondisi politik, ekonomi, sosial, budaya, dan kemasyarakatan yang ada. Artinya, dengan berbagai situasi dan kondisi yang ada, penyelenggara ibadah haji dan umrah wajib dilaksanakan sebagai tugas nasional yang sesuai dengan Undang-Undang No. 13 Tahun 2008 tentang ibadah haji, bahwa penyelenggaraan ibadah haji bertujuan memberikan pembinaan, pelayanan dan perlindungan yang sebaik baiknya bagi jamaah haji hingga mereka dapat menunaikan ibadah sesuai dengan ketentuan ajaran agama Islam.

Ibadah haji bertujuan untuk meningkatkan ketakwaan dan nilai-nilai spiritual pelakunya, tetapi haji juga menyimpan potensi ekonomi yang sangat potensial (berdasarkan akademis). Ada belasan sektor industri, manufaktur, perdagangan, jasa yang terlibat dalam muktamar internasional tahunan umat Is- lam itu. Peluang inilah yang dilirik bukan saja oleh pemerintah namun juga oleh biro-biro peyelenggara haji yang berkompetisi untuk menarik simpati jamaah. Kesemuanya itu berlomba-lomba menawarkan pembinaan, pelayanan perlindungan dengan kelebihan fasilitas yang berbeda untuk popularitas.

Pelayanan kepada pelanggan dalam hal ini masyarakat merupakan tujuan utama yang tidak dapat dihindarkan. Para administrator negara akan lebih memahami kebutuhan dan harapan masyarakat dengan mempelajari manajemen pelayanan. Menciptakan pelayanan yang terbaik kepada masyarakat dalam organisasi pemerintahan pada akhirnya akan mencapai tiga tujuan, yaitu: (1) meningkatkan efisiensi dan efektifitas pelayanan yang harus disediakan oleh pemerintah kepada masyarakat, (2) peningkatan pelayanan akan memberi kepuasan dan kemudahan kepada masyarakat sehingga akan menumbuhan citra yang baik terhadap organisasi pemerintah, dan (3) pela- 
yanan yang efisien dan efektif akan merangsang aktivitas masyarakat terutama dalam bidang ekonomi. Terlaksananya ketiga tujuan tersebut tergantung pada strategi dan kebijakan manajemen yang dikembangkan, kemampuan adaptasi dan berkembang seirama dengan lingkungan yang senantiasa berubah, serta konsistensi dalam manajemen terapan secara menyeluruh.

Ciri pelayanan yang baik yang dapat memberikan kepuasan kepada jamaah adalah (1) memiliki karyawan yang professional, (2) tersedia sarana prasarana yang baik, (3) tersedia semua produk yang diinginkan, (4) bertanggungjawab kepada setiap jamaah dari awal hingga selesai, (5) mampu melayani secara cepat dan tepat, (6) mampu berkomunikasi secara jelas dan memiliki pengetahuan umum lainya, dan (7) mampu memberikan kepercayaan dan motivasi kepada semua jamaah.

Perusahaan travel haji dan umrah memiliki potensi yang mampu untuk berkiprah di dalam dunia bisnis ini, karena para pelaku usaha yang bergerak di bidang tour dan travel haji dan umrah mempunyai pasar yang berpotensi untuk dikembangkan. Mengembangkan usaha ini tentu memiliki persaingan yang cukup signifikan dengan tujuan untuk memperoleh keuntungan. Perusahaan harus lebih teliti menangkap peluang usaha dan harus lebih meningkatkan layanan yang diberikan kepada konsumen.

Berbagai bidang usaha tour dan travel haji dan umrah bertujuan untuk memudahkan segala bentuk aktifitas ibadah haji dan umrah. Berdasarkan data yang diperoleh dari asosiasi travel agent Indonesia (ASITA) pertumbuhan usaha wisata tour dan travel mengalami peningkatan sejak tahun 2013.

Tujuan penelitian ini adalah sebagai berikut ini.

1 Untuk mengetahui tingkat kualitas pelayanan PT Safina Assalam Tour saat ini.

2 Untuk mengetahui strategi PT Safina Assalam Tour dalam memberikan pelayanan kepada pelanggan.

\section{Kajian Literatur}

Manajemen strategi adalah seni dan pengetahuan dalam merumuskan, mengimplementasikan, serta mengevaluasi keputusan- keputusan lintas fungsional yang memungkinkan sebuah organisasi untuk mencapai tujuan (David, 2012:6). Manajemen strategi berfokus pada proses penetapan tujuan organisasi, pengembangan kebijakan dan perencanaan untuk mencapai sasaran, serta mengalokasikan sumber daya untuk menerapkan kebijakan dan merencanakan pencapaian tujuan organisasi. Manajemen strategis mengkombinasikan aktivitas-aktivitas dari berbagai bagian fungsional suatu bisnis untuk mencapai tujuan organisasi. Bambang (2003: 3) menyatakan bahwa strategi manajemen adalah suatu proses yang dirancang secara sistematis oleh manajemen untuk merumuskan strategi, menjalankan strategi dan mengevaluasi strategi dalam rangka menyediakan nilai-nilai yang terbaik bagi seluruh pelanggan untuk mewujudkan visi organisasi. Sejalan dengan pemikiran di atas, menurut Wheelen dan Hungger (2010:105), manajemen strategi adalah serangkaian keputusan manajerial dan kegiatan-kegiatan yang menentukan keberhasilan perusahaan dalam jangka panjang. Kegiatan tersebut terdiri dari perumusan/perencanaan strategi, pelaksanaan/implementasi dan evaluasi. Strategi merupakan bagian akhir dari bentuk permata pelayanan pada pelanggan, misi, nilai, tujuan dan strategi. Untuk mengubah visi dan misi menjadi kenyataan, pada saat tujuan pelayanan dan pelanggan.

Ada tiga tahap proses manajemen strategi, yaitu perumusan strategi, penerapan strategi dan penilaian strategi. Perumusan strategi mencakup (1) pengembangan visi dan misi, identifikasi peluang dan ancaman eksternal suatu organisasi, (2) kesadaran akan kekuatan dan kelemahan internal, dan (3) penetapan tujuan. Isu-isu perumusan strategi mencakup (1) penentuan bisnis apa yang akan dimasuki, (2) bisnis apa yang akan tidak dijalankan, (3) bagaimana pengalokasian sumber daya, (4) perlukah ekspansi atau diverifikasi operasi yang dilakukan, (5) perlukah merger atau penggabungan usaha dibuat, dan (6) bagaimana menghindari pengambil alihan yang merugikan.

Memahami arti manajemen strategi di atas, maka kiranya tidak berlebihan bila penelitian ini dimaksudkan sebagai input pada manajemen strategi khususnya pelayanan ha- 
ji dan umrah PT Safina Assalam Tour tentang peluangnya untuk membuka diri meninjau kembali strategi perusahaan saat ini.

Tahap-tahap manajemen strategi terdiri atas sebagai berikut ini.

1. Perencanaan (planning), sebagai salah satu fungsi manajemen.

2. Pengorganisasian (organizing), merupakan sistem kerjasama sekelompok orang, yang dilakukan dengan pembidangan dan pembagian seluruh pekerjaan atau tugas dengan membentuk sejumlah satuan atau unit kerja, yang menghimpun pekerjaan sejenis dalam satu-satuan kerja. Kemudian dilanjutkan dengan menetapkan wewenang dan tanggung jawab masing-masing diikuti dengan mengatur hubungan kerja baik secara vertikal maupun horizontal.

3. Pelaksanaan (actuating), dilakukan organisasi setelah sebuah organisasi memiliki perencanaan dan melakukan pengorganisasian dengan memiliki struktur organisasi termasuk tersedianya personil sebagai pelaksana sesuai dengan kebutuhan unit atau satuan kerja yang dibentuk.

4. Penganggaran (budgeting), merupakan salah satu fungsi manajemen yang sangat penting peranannya karena fungsi ini berkaitan tidak saja dengan penerimaan, pengeluaran, penyimpanan, penggunaan dan pertanggungjawaban, namun lebih luas lagi berhubungan dengan kegiatan tata laksana keuangan. Kegiatan fungsi anggaran dalam organisasi sektor publik menekankan pada pertanggungjawaban dan penggunaan sejumlah dana secara efektif dan efisien. Hal ini disebabkan karena dana yang dikelola tersebut merupakan dana masyarakat yang dipercayakan kepada organisasi sektor publik.

5. Pengawasan (control), dilakukan oleh manajer sektor publik terhadap pekerjaan yang dilakukan dalam satuan atau unit kerjanya. Kontrol diartikan sebagai proses mengukur (measurement) dan menilai (evaluation) tingkat efektivitas kerja personel dan tingkat efisiensi penggunaan sarana kerja dalam memberikan kontribusi pada pencapaian tujuan organisasi.

Manajemen strategi perlu diadakan Alasan utamanya adalah sebagai berikut ini.
1. Manajemen strategi membantu perusahaan melihat lebih dulu ancaman dan peluang di masa depan.

2. Manajemen strategi menyediakan sasaran yang jelas serta arah untuk masa depan perusahaan.

3. Riset dalam manajemen strategi dapat membantu para manajer. Hal ini kelihatannya mengesankan bahwa perencanaan formal membantu keberhasilan.

Berbagai riset menunjukan bahwa biaya mempertahankan pelanggan jauh lebih murah dibandingkan biaya merebut pelanggan. Oleh karena itu, mulai banyak perusahaan yang berusaha menekankan upaya memaksimalkan potensi penjualan masa depan bisnis pelanggan saat ini. Berikut ini ada tiga alternatif strategi yang dapat dipilih.

1. Mempertahankan tingkat kepuasan pelanggan yang tinggi. Banyak merek yang berhasil dibangun di pasar dengan memfokuskan strategi dan programnya untuk mempertahankan kepercayaan pelanggan terhadap kualitas produk yang superior. Loyalitas pelanggan tercipta manakala pelanggan membeli barang dan jasa dari sumber yang sama dari waktu ke waktu. Kepuasan pelanggan merupakan penyebab utama loyalitas, kepuasan dan loyalitas akan semakin kuat bila didukung pula dengan ekuitas merek yang kuat.

2. Relationship marketing, dirancang untuk meningkatkan kemungkinan terjadinya bisnis ulangan melalui pengembangan hubungan yang sifatnya formal-interpersonal dengan pelanggan.

3. Produk komplementer, merupakan salah satu bentuk strategi yang sering dirancang dan dipasarkan perusahaan dalam rangka mempertahankan pelanggan. Menambah jumlah relasi antara perusahaan dan pelanggan dapat menyebabkan peralihan ke pemasok atau merek lain menjadi lebih mahal (baik secara ekonomis maupun psikologis) bagi pelanggan.

Kualitas pelayanan (service quality) merupakan konsep yang abstrak dan banyak mengandung hal-hal yang bersifat psikologis maupun sosial. Beberapa pendekatan dilakukan untuk dibahas dan dianalisis secara aka- 
demis, dan tentunya diwujudkan dalam usaha layanan. Menurut J. Supranto (2006:226) kualitas pelayanan adalah sebuah kata yang bagi penyedia jasa merupakan sesuatu yang harus dikerjakan dengan baik. Menurut Garvin yang dikutip Tjiptono (2012:143) menyatakan bahwa terdapat lima perspektif mengenai kualitas, salah satunya yaitu bahwa kualitas dilihat tergantung pada orang yang menilainya, sehingga produk yang paling memuaskan preferensi seseorang merupakan produk yang berkualitas paling tinggi. Kualitas pelayanan adalah suatu tindakan yang dilakukan mulai dari awal sampai akhir yang dilakukan oleh direktur tertinggi sampai karyawan terendah untuk memenuhi kebutuhan calon ataupun pengguna barang dan jasa yang ditangani. Kualitas pelayanan juga dapat diartikan sebagai proses pemenuhan kebutuhan melalui aktifitas orang lain yang langsung diterima. Kotler (1993:240) menyusun faktorfaktor utama yang menjadi penentu mutu pelayanan utama. Pada dasarnya konsumen menggunakan kriteria yang sama apapun jenis jasanya.

1. Akses, di mana jasa tersebut mudah didapatkan pada tempat-tempat, waktu yang tepat tanpa banyak menunggu.

2. Komunikasi, di mana jasa tersebut dijelaskan dengan tepat dalam bahasa yang mudah dipahami dan sederhana.

3. Kompetensi, di mana para pegawai memiliki keahlian dan pengetahuan yang diperlukan.

4. Kesopanan, di mana para pegawai harus ramah, cepat tanggap dan tenang.

5. Kreadibilitas, di mana perusahaan dan karyawan dapat di percaya dan mempunyai tempat di hati konsumen.

6. Keandalan, di mana jasa yang diberikan secara konsisten dan tepat.

7. Responsif, di mana pelayanan atau respon karyawan yang cepat dan kreatif terhadap permintaan atau permasalahan yang dihadapi konsumen.

8. Keamanan, di mana jasa yang diberikan bebas dari bahaya, resiko dan keraguan.

9. Bagian-bagian dari jasa yang berbentuk fisik benar-benar mencerminkan kualitas jasa tersebut.

10. Memahami konsumen, di mana karyawan benar-benar membuat usaha memahami kebutuhan konsumen dan memberikan perhatian secara individual.

Jasa sering dipandang sebagai suatu fenomena yang rumit. Kata jasa itu sendiri mempunyai banyak arti dari mulai pelayanan personal (personal service) sampai jasa sebagai suatu produk. Sejauh ini, sudah banyak pakar pemasaran jasa yang telah berusaha mendefinisikan pengertian jasa. Kotler (2005:464) menyebutkan bahwa pelayanan (service) dapat didefinisikan sebagai suatu tindakan atau kinerja yang diberikan oleh seseorang kepada orang lain. Pelayanan (service) dapat diklasifikasikan sebagai berikut ini.

1. High contact service, di mana kontak antara konsumen dan penyedia jasa yang sangat tinggi, konsumen selalu terlibat dalam proses dari layanan jasa tersebut.

2. Low contact service, di mana kontak antara konsumen dengan penyedia jasa tidak terlalu tinggi. Kontak fisik dengan konsumen hanya terjadi di frontdesk. Contohnya adalah lembaga keuangan.

Jasa adalah setiap tindakan atau kegiatan yang ditawarkan oleh suatu pihak kepada pihak lain, yang pada dasarnya tidak terwujud dan tidak mengakibatkan kepemilikan apapun. Produksinya dapat dikaitkan atau tidak dengan suatu produk fisik (Kotler, 2005: 486). Jasa mencakup semua aktivitas ekonomi yang hasilnya bukanlah produk atau konstruksi fisik, yang secara umum konsumsi dan produksinya dilakukan pada saat bersamaan, dan nilai tambah yang diberikannya dalam bentuk (kenyamanan, hiburan, kecepatan, dan kesehatan) yang secara prinsip tidak berwujud pada pembeli pertamanya (Zeithaml, 2003:3). Dari berbagai definisi di atas, tampak bahwa di dalam jasa selalu ada aspek interaksi antara pihak konsumen dan pemberi jasa, meskipun pihak-pihak yang terlibat tidak selalu menyadari. Jasa juga bukan merupakan barang, jasa adalah suatu proses atau atau aktifitas yang tidak berwujud. Jadi pada dasarnya jasa merupakan semua aktivitas ekonomi yang hasilnya tidak merupakan produk dalam bentuk fisik atau kontruksi, yang biasanya dikonsumsi pada saat yang sama dengan waktu yang di hasilkan dan memberi 
nilai tambah (seperti misalnya kenyamanan, hiburan, kesehatan, dan kesenangan) atau pemecahan atas masalah yang dihadapi konsumen memiliki empat ciri utama yang sangat mempengaruhi desain dan rancangan program pemasarannya (Kotler, 2005: 228-241), sebagai berikut ini.

1. Intangibility (tidak berwujud), artinya jasa tidak dapat dilihat, dirasakan, dicecap, didengar atau diraba sebelum dibeli.

2. Inseparability (tidak dapat dipisahkan), artinya bahwa jasa dalam hal ini tidak berlaku pada barang fisik yang di produksi, ditempatkan pada persediaan, distribusi melalui berbagai pengecer dan akhirnya dikonsumsi jika jasa diberikan oleh seseorang maka orang tersebut adalah merupakan bagian dari jasa tersebut.

3. Variability (bervariasi), artinya bahwa mutu jasa tergantung kepada siapa yang menyediakan jasa disamping waktu, tempat, dan bagaimana disediakan. Dan pembeli jasa akan berhati-hati terhadap keragaman seperti ini dan seringkali membicarakannya dengan yang lain sebelum memilih seorang penyedia.

4. Perishability (tidak tahan lama), artinya jasa tidak dapat di simpan untuk dijual atau di pakai kemudian.

\section{Dimensi Kualitas Pelayanan}

Parasuraman, Zeithaml, dan Berry (dalam Tjiptono, 2012:69) yang melakukan penelitian khusus terhadap beberapa jenis pelayanan, mengidentifikasi sepuluh faktor utama yang menentukan kualitas pelayanan, yakni sebagai berikut ini.

1. Reliability, yang mencakup konsistensi kerja (performance) dan kemampuan untuk dipercaya (dependability). Hal ini berarti perusahaan memberikan pelayanannya secara tepat sejak awal (right the first time) dan telah memenuhi janji (iklan)nya.

2. Responsiveness, yaitu kemauan atau kesiapan para pegawai untuk memberikan pelayanan yang dibutuhkan pelanggan.

3. Competence, artinya setiap pegawai perusahaan memiliki pengetahuan dan keterampilan yang dibutuhkan untuk dapat memberikan pelayanan tertentu.

4. Access, yaitu kemudahan untuk dihubungi atau ditemui, yang berarti lokasi fasilitas pelayanan mudah dijangkau, waktu menunggu tidak terlalu lama, dan saluran komunikasi mudah dihubungi.

5. Courtesy, yaitu sikap sopan santun, respek, perhatian, dan keramahan dari para kontak personal perusahaan

6. Communication, yaitu memberikan informasi yang dapat dipahami pelanggan serta selalu mendengarkan saran dan keluhan pelanggan.

7. Credibility, yaitu jujur dan dapat dipercaya. Di sini menyangkut nama dan reputasi perusahaan, karakteristik pribadi, kontak personal, dan interaksi dengan pelanggan.

8. Security, yaitu aman (secara fisik, finansial dan kerahasiaan) dari bahaya, risiko atau keragu-raguan.

9. Understanding/knowing the customer, yaitu upaya untuk memahami kebutuhan pelanggan.

10. Tangible, yaitu segala bukti fisik seperti pegawai, fasilitas, peralatan, tampilan fisik dari pelayanan.

Namun, dalam perkembangan selanjutnya Parasuraman et al., (dalam Zeithaml dan Bitner (1996:118) sampai pada kesimpulan bahwa kesepuluh dimensi kualitas pelayanan di atas dirangkumkan menjadi lima dimensi pokok yang terdiri dari reliability, responsiveness, assurance (yang mencakup competence, courtesy, credibility, dan security), empathy (yang mencakup access, communication dan understanding the customer), serta tangible.

Kualitas pelayanan (service quality) sangat bergantung pada tiga hal yaitu: sistem, teknologi, dan manusia. Faktor manusia memegang kontribusi terbesar sehingga kualitas pelayanan relatif lebih sulit ditiru disbandingkan dengan kualitas produk dan harga. Salah satu konsep kualitas layanan yang popular adalah servqual, yaitu sebagai berikut ini.

1. Bukti langsung/fisik (tangible), yaitu bukti nyata dari pelayanan yang diberikan, meliputi fasilitas fisik, perlengkapan, karyawan dan sarana komunikasi. Menimbang bahwa suatu layanan tidak dapat dilihat, dicium, diraba, maka aspek tangible menjadi penting sebagai ukuran pelayanan. 
2. Keandalan (reliability), yaitu dimensi yang mengukur keandalan perusahaan dalam memberikan pelayanan kepada pelanggannya, dibandingkan empat dimensi kualitas layanan yang lain, dimensi ini dipersepsikan paling penting dalam berbagai industry jasa.

3. Daya tanggap (responsiveness), di mana harapan pelanggan terhadap kecepatan pelayanan tidak akan cenderung meningkat dari waktu ke waktu. Perlu diingat bahwa, harga pada suatu waktu bisa dipersepsikan berbeda antara satu pelanggan dan pelanggan yang lain.

4. Jaminan (assurance), yaitu dimensi yang berhubungan dengan kemampuan perusahaan dan perilaku staff front-line dalam menanamkan rasa percaya dan keyakinan pada pelanggan.

5. Empati (emphaty), di mana pelanggan dari kelompok menengah atas mempunyai harapan yang tinggi agar perusahaan penyedia jasa mengenal mereka secara pribadi. Perusahaan harus tahu nama mereka, kebutuhan mereka secara spesifik dan bila perlu mengetahui hobi dan karakter pribadi mereka lainnya.

\section{Metode Penelitian}

Penelitian ini adalah penelitian deskriptif. Menurut Sugiyono (2010:29) penelitian deskriptif adalah metode yang digunakan untuk menggambarkan atau menganalisis suatu hasil penelitian tetapi tidak digunakan untuk membuat kesimpulan yang lebih luas. Metode deskriptif digunakan untuk menggambarkan rumusan masalah ke satu, dua dan tiga. Data yang dibutuhkan adalah data yang sesuai dengan masalah-masalah yang ada dan sesuai dengan tujuan penelitian, sehingga data tersebut akan dikumpulkan, dianalisis dan diproses lebih lanjut sesuai dengan teori-teori yang telah dipelajari. Jadi, dari data tersebut akan ditarik kesimpulan.

Menurut Malhotra (2009:364), populasi adalah gabungan seluruh elemen, yang memiliki serangkaian karakteristik serupa, yang mencakup semesta untuk kepentingan masalah riset pemasaran. Populasi dalam penelitian ini adalah seluruh jamaah atau konsumen yang pernah menggunakan jasa PT Safina Assalam Tour.
Menurut Malhotra (2009:364), sampel adalah sekelompok elemen populasi yang terpilih untuk berpartisipasi dalam studi. Sampel adalah bagian dari populasi yang diambil melalui cara-cara tertentu yang mewakili populasi. Penelitian mengenai kualitas pelayanan di PT Safina Assalam Tour ini dilaksanakan dengan menggunakan metode nonprobabilitas (pengambilan sampel secara tidak acak) dengan menggunakan tekhnik pengambilan sampel bertujuan, di mana sampel dipilih berdasarkan karakteristiknya.

Apabila populasi tidak diketahui, Hair dkk. (2007) merekomendasikan jumlah sampel minimal lima kali dari jumlah item pertanyaan yang terdapat di kuesioner. Total pertanyaan dalam penelitian ini adalah 10 pertanyaan, sehingga minimal ukuran sampel penelitian ini adalah 50 pertanyaan.

Sumber data dalam penelitian ini terdiri atas data primer dan data sekunder. Data primer adalah data yang diperoleh secara langsung dari objek yang diamati. Data primer diperoleh dengan tanya jawab pada beberapa bagian yang terkait dalam penelitian. Data sekunder adalah data penelitian yang diperoleh oleh peneliti secara tidak langsung melalui media perantara (diperoleh dan dicatat oleh pihak lain), serta dokumen-dokumen lainnya yang berhubungan dengan penelitian.

Analisis deskriptif adalah mentransformasi data mentah ke dalam bentuk data yang mudah dimengerti dan ditafsirkan, serta menyusun, manipulasi dalam menyajikan supaya menjadi suatu informasi. (Kusmayadi: 2000). Setelah data terkumpul secara lengkap di lapangan, langkah selanjutnya adalah menganalisis data tersebut. Dengan tahapan sebagai berikut ini.

1. Kuesioner yang telah diisi oleh responden diri penomoran sesuai dengan jumlah responden.

2. Hasil dari kuesioner dimasukkan ke dalam data ordinal melalui program excel. Data ordinal ini menunjukkan tentang tingkat kualitas pelayanan dengan mengunakan skala Likert dengan alasan agar responden dapat dengan mudah mengukur dengan skala berapa yang menyatakan sangat setuju sampai sangat tidak setuju. Penilaian dalam skala Likert dapat dilihat pada Tabel 1 berikut ini. 
Tabel 1. Penilaian dalam Skala Likert

\begin{tabular}{cc}
\hline Nilai & Keterangan \\
\hline 5 & Sangat Setuju (SS) \\
\hline 4 & Setuju (S) \\
\hline 3 & Ragu-Ragu (R) \\
\hline 2 & Tidak Setuju (TS) \\
\hline 1 & Sangat Tidak Setuju (STS) \\
\hline
\end{tabular}

\section{Hasil Penelitian dan Pembahasan}

Dalam penelitian ini, terdapat 10 faktor yang dapat mempengaruhi kualitas pelayanan kepada pelanggan. Kesepuluh faktor ini akan diwakili oleh petanyaan yang akan mengambarkan kualitas pelayanan.

Berdasarkan hasil penelitian dapat diketahui dari 50 responden yang mengisi kuesioner, sebanyak 26 responden dengan persentase 53,8\% merasa ragu bahwa karyawan belum dapat diandalkan dalam mengurus semua dokumen dengan baik dan cepat sehingga pelanggan masih belum puas akan pelayanan yang diberikan. Nilai ini merupakan persentase tertinggi ini merupakan kendala besar bagi Safina Assalam Tour. Namun 20 responden $(42,3 \%)$ merasa setuju dan sebanyak 4 responden $(3,8 \%)$ merasa sangat setuju mampu. Hal ini dapat dilihat pada Tabel 2

Pelanggan ingin langsung mendapatkan informasi dari karyawan tanpa harus dialihkan kepada karyawan yang lain. Ini dapat membuat ketidak nyamanan pelangan dalam mendapatkan informasi dan terkadang harus menunggu karena karyawan yang mengerti tentang pengurusan dokumen tersebut karena tidak ada di tempat. Ini merupakan kendala yang serius pada Safina Assalam Tour. Kecenderungan pelanggan biasanya enggan untuk menunggu lama dan memutuskan untuk pindah ke biro perjalanan wisata lainnya.

Tabel 2. Faktor Keandalan (Reliablitiy)

\begin{tabular}{ccc}
\hline Keterangan & Frekuensi & Persentease \\
\hline STS & 0 & 0 \\
\hline TS & 0 & 0 \\
\hline R & 26 & 53,8 \\
\hline S & 20 & 42,3 \\
\hline SS & 4 & 3,8 \\
\hline Total & 50 & 100,0 \\
\hline
\end{tabular}

Kemampuan staff Safina Assalam Tour memberikan pelayanan yang cepat dan tepat sesuai dengan yang diinginkan oleh para pelanggan. Dari 50 responden, 26 responden
$(53,8 \%)$ merasa setuju bahwa pelayanan yang diberikan staff cepat dan tepat. Kualitas layanan ini masih perlu adanya peningkatan karena responden yang menjawab ragu-ragu sengan persentase yang cukup tinggi sebesar 24 responden $(46,2 \%)$. Jadi, dapat disimpulkan hasil pengolahan data yang didapatkan staff Safina Assalam Tour telah mampu memberikan kualitas pelayanan yang baik kepada pelanggannya. Hal ini dapat dilihat pada Tabel 3.

\begin{tabular}{ccc}
$\begin{array}{l}\text { Tabel 3. } \\
\text { (Responsiveness) }\end{array}$ & Faktor & Kesiapan/Kemauan \\
\hline Keterangan & Frekuensi & Persentease \\
\hline STS & 0 & 0 \\
\hline TS & 0 & 0 \\
\hline R & 24 & 46,2 \\
\hline S & 26 & 53,8 \\
\hline SS & 0 & 0 \\
\hline Total & 50 & 100,0 \\
\hline
\end{tabular}

Berdasarkan hasil penelitian, dapat dilihat bahwa dari 50 responden dari jumlah responden sebanyak 38 responden $(76,9 \%)$ merasa setuju staff mampu memberikan semua informasi yang diinginkan oleh para pelanggan. Pelanggan dapat mengunakan semua produk yang ditawarkan sehingga pelanggan senang dan puas akan pelayanan dan informasi yang diberikan staff. Kemampuan ini sangat diperlukan sehingga proses penjualan jasa dapat berjalan dengan baik dan tamu yakin akan membeli produk yang ditawarkan. Pernyataan ini diperkuat lagi dengan 8 responden $(15,4 \%)$ merasa sangat setuju akan kemampuan staff dalam memberikan informasi produk. Namun, masih ada responden ragu dengan kemampuan staff sebesar 4 responden $(7,7 \%)$ merasa ragu-ragu. Dapat diartikan bahwa staff sudah sangat baik dalam membarikan informasi yang diinginkan dan menguasai produk yang ditawarkan. Hal ini dapat dilihat pada Tabel 4

Tabel 4. Faktor Keterampilan (Competence)

\begin{tabular}{ccc}
\hline Keterangan & Frekuensi & Persentease \\
\hline STS & 0 & 0 \\
\hline TS & 0 & 0 \\
\hline R & 4 & 7,7 \\
\hline S & 38 & 76,9 \\
\hline SS & 8 & 15,4 \\
\hline Total & 50 & 100,0 \\
\hline
\end{tabular}


Kemampuan staff yang memberikan kemudahan untuk ditemui atau dihubungi semua yang ingin diketahui oleh para pelanggan dengan baik dan jelas sudah sangat baik, dapat dilihat 38 responden $(76,9 \%)$. Hal ini didukung oleh fasilitas Safina Assalam Tour yang cukup memadai untuk mencari informasi yang berhubungan dengan produk yang ditawarkan. Terdapat 9 responden $(19,2 \%)$ merasa sangat setuju dan yang terkecil sebesar 3 responden $(3,8 \%)$ merasa ragu-ragu. Dapat diartikan, staff sudah berusaha semampunya untuk memberikan kemudahan atau dihubungi bagi para pelanggannya agar informasi-informasi bisa tersampaikan dengan jelas ke telinga pelanggan dengan baik. Jawaban responden atas pertanyaan tentang faktor kemudahan dapat dilihat pada Tabel 5 berikut ini.

Tabel 5. Faktor Kemudahan (Access)

\begin{tabular}{ccc}
\hline Keterangan & Frekuensi & Persentase \\
\hline STS & 0 & 0 \\
\hline TS & 0 & 0 \\
\hline R & 3 & 3,8 \\
\hline S & 38 & 76,9 \\
\hline SS & 9 & 19,2 \\
\hline Total & 50 & 100,0 \\
\hline
\end{tabular}

Berdasarkan hasil penelitian, dapat dilihat bahwa dari 50 responden yang mengisi kuesioner, sebanyak 39 responden $(73,1 \%)$ merasa setuju staff memberikan pelayanan sopan, ramah, simpatik dan profesional kepada semua pelanggan, sedangkan 11 responden $(26,9 \%)$ merasa sangat setuju. Dapat disimpulkan dari hal ini, bahwa semua konsumen sudah merasa setuju dengan kesopanan dan keramahan. Hal ini akan menjadi nilai tambah bagi perusahaan dalam meningkatkan pelayanannya. Hasil jawaban responden atas faktor respek dapat dilihat pada Tabel 6 .

Tabel 6. Faktor Respek (Courtesy)

\begin{tabular}{ccc}
\hline Keterangan & Frekuensi & Persentase \\
\hline STS & 0 & 0 \\
\hline TS & 0 & 0 \\
\hline R & 0 & 0 \\
\hline S & 39 & 73,1 \\
\hline SS & 11 & 26,9 \\
\hline Total & 50 & 100,00 \\
\hline
\end{tabular}

Berdasarkan hasil penelitian, dapat dilihat bahwa dari 50 responden yang mengisi kuesioner, sebanyak 39 responden $(80,8 \%)$ merasa ragu-ragu staff dapat menangani semua keluhan dengan baik dan professional. Persentase ragu-ragu yang sangat tinggi ini merupakan halangan yang harus di perhatikan oleh pihak Safina Assalam Tour. Perlunya ada perhatian khusus karena ada ketidakyakinan pelanggan dalam melakukan pembelian jasa. Mereka khawatir bila terjadi sebuah kendala staff tidak dapat menyelasaikan keluhan dan tidak memberikan penyelesaian keluhan yang sesuai dengan yang diinginkan oleh pelanggan. Terdapat 11 responden $(19,2 \%)$ merasa setuju kemampuan staff dalam menangani semua keluhan dengan baik. Jadi, dapat disimpulkan bahwa staff belum sepenuhnya bisa menghadapi keluhan yang datang dari pelanggan. Hal ini disebabkan staff tidak dapat memberikan keputusan yang tepat dan cepat untuk menyelesaikan masalah. Jawaban responden atas faktor komunikasi dilihat pada Tabel 7 berikut ini.

Tabel 7. Faktor Komunikasi (Commmunica-tion)

\begin{tabular}{ccc}
\hline Keterangan & Frekuensi & Persentase \\
\hline STS & 0 & 0 \\
\hline TS & 0 & 0 \\
\hline R & 39 & 80,8 \\
\hline S & 11 & 19,2 \\
\hline SS & 0 & 0 \\
\hline Total & 50 & 100.0 \\
\hline
\end{tabular}

Bentuk kepercayaan dan kejujuran yang baik sangatlah penting. Baiknya kepercayaan dan kejujuran yang terjalin antara staff dan pelanggan akan membuat nyaman pelanggan untuk melakukan membeli jasa pada Safina Assalam Tour. Staff telah mampu memberikan kepercayaan dan kejujuran dengan baik kepada pelanggan. Hal ini dapat dilihat pada hasil penelitian terdapat 29 responden $(57,7 \%)$ merasa setuju, sedangkan 21 responden $(42,3 \%)$ merasa sangat setuju. Dari hasil penelitian ini dapat dilihat pelanggan sudah sangat puas dengan cara staff menjaga kepercayaan yang dilakukan oleh staff. Jawaban responden atas faktor dapat dipercaya dapat dilihat pada Tabel 8 sebagai berikut ini. 
Tabel 8. Faktor Dapat Dipercaya (Credibility)

\begin{tabular}{ccc}
\hline Keterangan & Frekuensi & Persentase \\
\hline STS & 0 & 0 \\
\hline TS & 0 & 0 \\
\hline R & 0 & 0 \\
\hline S & 29 & 57,7 \\
\hline SS & 21 & 42,3 \\
\hline Total & 50 & 100,0 \\
\hline
\end{tabular}

Keamanan bagi para pelanggan sangatlah penting bagi pihak Safina Assalam Tour. Hal ini terlihat dari kemudahan dan keamanan bagi para pelanggan dalam melakukan transaksi. Semua telah di pikirkan oleh pihak Safina Assalam Tour dalam menjaga keamanan bagi pelanggannya. Kepuasan pelanggan akan keamanan kantor terlihat dari hasil penelitian, yaitu dari 50 responden yang mengisi kuesioner, sebanyak 47 responden (96,2\%) merasa setuju bahwa staff mampu memberikan kenyamanan dan keamanan bagi semua para pelanggannya, sedangkan 3 responden $(3,8 \%)$ merasa sangat setuju. Jadi, dapat disimpulkan bahwa keamanan untuk pelanggan di PT Safina Assalam Tour sudah cukup baik. Akan lebih baik lagi jika pengamanan itu bervariasi contoh, untuk pembayaran menggunakan sistem transfer. Jawaban responden atas pertanyaan faktor keamanan dapat dilihat pada Tabel 9.

Tabel 9. Faktor Keamanan (Security)

\begin{tabular}{ccc}
\hline Keterangan & Frekuensi & Persentase \\
\hline STS & 0 & 0 \\
\hline TS & 0 & 0 \\
\hline R & 0 & 0 \\
\hline S & 47 & 96,2 \\
\hline SS & 3 & 3,8 \\
\hline Total & 50 & 100,0 \\
\hline
\end{tabular}

Berdasarkan hasil penelitian, dapat dilihat bahwa dari 50 responden yang mengisi kuesioner, sebanyak 42 responden $(84,6 \%)$ merasa setuju staff dapat tanggap dengan apa kebutuhan yang diperlukan oleh para pelanggan sehingga merasa apa yang diingikan dapat diwujudkan, sedangkan 4 responden $(7,7 \%)$ merasa sangat setuju dan yang yang terkecil sebesar 4 responden $(7,7 \%)$ merasa ragu-ragu. Jawaban responden atas pertanyaan tentang faktor kebutuhan pelanggan dapat dilihat pada Tabel 10.
Tabel 10. Faktor Kebutuhan Pelanggan (Understanding)

\begin{tabular}{ccc}
\hline Keterangan & Frekuensi & Persentase \\
\hline STS & 0 & 0 \\
\hline TS & 0 & 0 \\
\hline R & 4 & 7,7 \\
\hline S & 42 & 84.6 \\
\hline SS & 4 & 7,7 \\
\hline Total & 50 & 100,0
\end{tabular}

Pemilik Safina Assalam Tour menyediakan fasilitas kantor yang mendukung seperti interior kantor yang besih dan rapi sehingga pelanggan merasa nyaman berada di Safina Assalam Tour. Kenyaman ini diciptakan tidak hanya untuk para pelanggan, namun juga untuk para staff agar mereka dapat melakukan pekerjaannya nyaman. Dari hasil penelitian dari 50 responden, sebanyak 41 responden $(80,8 \%)$ merasa setuju Safina Assalam Tour memiliki fasilitas kantor yang yang nyaman dan rapi, sedangkan 9 responden $(19,2 \%)$ merasa sangat setuju. Jawaban responden atas pertanyaan faktor fasilitas kantor dapat dilihat pada Tabel 11.

Tabel 11. Faktor Fasilitas Kantor

\begin{tabular}{ccc}
\hline Keterangan & Frekuensi & Persentase \\
\hline STS & 0 & 0 \\
\hline TS & 0 & 0 \\
\hline R & 0 & 0 \\
\hline S & 41 & 80.8 \\
\hline SS & 9 & 19.2 \\
\hline Total & 50 & 100.0 \\
\hline
\end{tabular}

Kesepuluh dimensi kualitas pelayanan menunjukan bahwa kualitas pelayanan di PT Safina Assalam Tour sudah baik. Semua pendapat dari pelanggan langsung ditanggapi serius oleh pemilik dan direktur utama Safina Assalam Tour agar peningkatan kualitas pelayanan. Bapak H. Syahlanny berusaha selalu mengevaluasi kinerja dari semua staff-nya. Ada salah satu pertanyaan yang mendapatkan jawaban ragu-ragu pada Tabel 2 yaitu dalam pengurusan dokumen dengan baik dan cepat sebanyak $53,8 \%$ pelanggan masih ragu-ragu kemampuan ini, walaupun pada hasil penelitian ini sebenarnya juga sudah cukup bagus karena 20 responden $(42,3 \%)$ merasa setuju dan sebanyak 4 responden $(3,8 \%)$ merasa sangat setuju mampu. Dalam hal ini ragu-ragu bukanlah sesuatu yang harus diperdebatkan 
karena masih banyak pula yang merasa setuju. Saat ini pihak Safina Assalam Tour secara rutin memberikan pelatihan tentang pengurusan dokumen secara bergiliran. Pemilihan bagian inbound yang diberi pelatihan karena staff bagian inbound lebih mudah untuk mengerti dan mereka telah bisa melakukan pengurusan perjalanan wisata. Pengurusan dokumen biasanya lebih pada perjalanan yang akan di lakukan keluar negeri (outbound). Staff bagian inbound diajari bagaimana prosedur dalam pengurusan dokumen mulai dari proses reservasi semua dokumen, prosedur pengurusan setiap dokumen seperti pasport, visa, bookingan hotel, room list, tiket pesawat dan persiapan dokumen sebelum keberangkatan. Perbaikan dalam peningkatan kualitas pelayanan dalam pengurusan dokumen yang dilakukan pihak Safina Assalam Tours sudah sangat baik, namun perlu ada untuk melihat pengurusan dokumen dari travel-travel agen besar yang ada seperti Kaltrabu Tour di Banjarmasin yang telah memiliki pengalaman yang banyak dalam pengurusan dokumen sehingga pihak Safina Assalam Tour dapat memperbaiki kelemahan dalam pengurusan dokumen agar dapat tertangani dengan cepat dan baik.

Selain itu, penambahan staff pada pengurusan dokumen perlu dilakukan dengan menerima staff baru yang memiliki latar belakang dari pariwisata. Hal ini dilakukan agar dapat meningkatkan kualitas dari perusahaan. Saat ini Safina Assalam Tour menerima dua staff baru yang sedang magang dari sekolah pariwisata khususnya untuk bagian tour. Hal ini dilakukan karena pada umumnya mereka lebih cepat mengerti tentang prosedur-prosedur yang ada di perusahaan. Mereka telah memiliki standar dalam pelayanan sesuai dengan nasional dan internasional. Tindakan yang diambil oleh pihak Safina Assalam Tours sudah sangat baik perlunya untuk memikirkan regenerasi staff yang ada.

Berdasarkan hasil observasi, staff Safina Assalam Tour sudah cukup banyak yang senior. Mereka cendrung telah malas untuk belajar sesuatu sehingga semangat kerjapun mulai menurun. Memikirkan perekrutan staff baru berdampak baik dalam kualitas pelayanan sehingga kreatifitas dan semangat kerja semakin baik.
Berdasarkan hasil penelitian, $80,8 \%$ pelanggan merasa ragu-ragu dalam cara staff menangani semua keluhan dengan baik. Hal ini masih jadi kendala untuk saat ini. Dari hasil penelitian 11 responden $(9,2 \%)$ merasa setuju akan kemapuan staff menangani semua keluhan dengan baik, artinya staff sudah bisa meyakinkan walaupun juga ada yang belum bisa menjawab karena masih ragu-ragu. Saat ini Safina Assalam Tour berusaha untuk memperbaiki kesalahan-kesalahan sekecil apapun dengan cara memberi contoh bagaimana saat manager menyelesaikan keluhan yang ada sehingga pelangan puas dengan penyelesaian keluhannya. Contoh yang diberikan tersebut diharapkan dapat dicontoh bila terjadi keluhan yang sama staff telah mampu menangani dengan baik. Pihak Safina Assalam Tour juga memberikan pengetahuan tentang karakteristik pelanggan. Ini sangat membantu dalam menghadapi keluhan yang datang, sehingga penyelesaian keluhan yang datang dapat diselesaikan dengan baik. Selain itu, penting sekali adanya pelatihan dalam menghadapi keluhan pelanggan dengan mendatangkan tim pelatihan dari psikologi Universitas Islam Banjarmasin. Tujuannya agar dapat mengetahui cara yang benar dalam menghadapi keluhan dan dapat membaca dengan cepat karakter pelanggan sehingga keluhan dapat dihadapi dengan baik, dan pelanggan puas dengan penyelesaian yang diberikan.

Berdasarkan hasil penelitian, upaya strategi yang dilakukan Safina Assalam Tour sudah baik. Namun, yang perlu diperhatikan dalam memberi pelayanan seperti yang dipaparkan oleh Payne (2000:33) pelayanan adalah rasa menyenangkan atau tidak menyenangkan dan oleh penerima pelayanan pada saat memperoleh pelayanan. Payne (2000) juga mengatakan bahwa pelayanan pelanggan mengandung pengertian:

1. segala kegiatan yang dibutuhkan untuk menerima, memproses, menyampaikan dan memenuhi pesanan pelanggan dan untuk menindak lanjuti setiap kegiatan yang mengandung keliruan;

2. Ketepatan waktu dan reliabilitas penyampaian jasa kepada pelanggan sesuai dengan harapan mereka; 
3. Serangkaian kegiatan yang meliputi semua bidang bisnis yang terpadu untuk menyampaikan produk-produk dan jasa tersebut sedemikian rupa sehingga dipresepsikan memuaskan oleh pelanggan dan merealisasikan pencapaian tujuan-tujuan perusahaan;

4. Total pesanan yang masuk dan seluruh komunikasi dengan pelanggan; dan

5. Penyampaian produk kepada pelanggan tepat waktu dan akurat dengan segala tindak lanjut serta tanggapan keterangan yang akurat.

Pengertian ini merupakan hal yang penting yang perlu diperhatikan dalam memberikan pelayanan kepada pelanggan. Dari kelima pengertian ini Safina Assalam tour menyampaikann produk kepada pelanggan masih belum tepat waktu dan akurat. Pada teori kepuasan pelangan menurut Irawan (2009:61) faktor keandalan (reliability) merupakan faktor yang terpenting dalam kepuasan pelanggan salah satu nya tepat waktu sesuai dengan janji. Dalam bisnis jasa modal kepercayaan merupakan kuncinya dari kepuasan pelanggan terhadap pelayanan yang diberikan.

Upaya yang harus di upayakan untuk meningkatan strategi kualitas pelayanan di perusahaan ini adalah sebagai berikut ini.

1. Faktor keandalan (reliability), yaitu dengan meningkatkan kemampuan perusahaan untuk memberikan pelayanan seperti yang dijanjikan.

2. Faktor kesiapan/kemauan (responsiveness), yaitu dengan memberikan pelayanan yang cepat kepada pelanggan.

3. Faktor keterampilan (competence), yaitu dengan menguasai produk dengan baik agar pelanggan lebih cepat mengerti mengenai apa yang diinginkannya.

4. Faktor emudahan (access), yaitu dengan memberikan kemudahan untuk dihubungi bagi para pelanggannya agar informasi-informasi bisa tersampaikan dengan jelas ke telinga pelanggan.

5. Faktor ramah dan sopan (courtesy), yaitu dengan memberikan pelayanan yang ramah dan sopan kepada pelanggan.

6. Faktor komunikasi (communication), yaitu dengan melakukan komunikasi dan kerja sama yang baik antara perusahaan dan pelanggan.

7. Faktor dapat dipercaya (credibility), yaitu dengan mampu menjaga kepercayaan para pelanggan dalam memberikan pelayanan.

8. Faktor keamanan (security), yaitu dengan menjaga reputasi perusahaan dengan baik, sehingga akan menumbuhkan rasa aman bagi para pelanggannya.

9. Faktor kebutuhan pelanggan (understanding), yaitu dengan memahami apa yang dibutuhkan pelanggan dengan cepat.

10. Faktor fasilitas kantor (tangible), yaitu dengan menjaga penampilan kantor dan staff dengan baik yang merupakan gambaran kualitas pelayanan yang baik pula, dan mampu memberikan impresi positif.

Pihak Safina Assalam Tour pada umumnya telah melakukan upaya ini. Namun, ada beberapa upaya yang belum dilakukan dengan baik yaitu pada memberikan pelayanan yang cepat dan mampu menepati janji sesuai dengan waktu yang telah disepakati dengan pelanggan. Selain itu, perusahaan perlu meningkatan kemampuan staff untuk lebih akurat dalam proses transaksi pembelian jasa hingga jasa akan diserahkan kepada pelanggan.

\section{Kesimpulan}

Berdasarkan pembahasan hasil penelitian, dapat disimpulkan beberapa hal sebagai berikut ini.

1. Kualitas pelayanan Safina Assalam Tour sudah baik ini dilihat dari persentase dari 10 pertanyaan yang menujukan persentase lebih dari $80 \%$. Kualitas pelayanan yang diberikan staff telah baik namun terdapat dua yang masih menjawab ragu-ragu. Atas hasil ini diharapkan bisa langsung dapat penanganan dengan baik sesuai dengan usulan yang ada.

2. Strategi peningkatan kualitas pelayanan di Safina Assalam Tour terus dilakukan oleh perusahaan yaitu salah satunya caranya dengan memberikan pengetahuan tentang pengurusan dokumen kepada seluruh staff, agar pengurusan dokumen dapat lebih cepat. Perekrutan staff baru dengan latar belakang pariwisata merupakan strategi yang dilakukan oleh perusahaan. 
Beberapa saran yang dapat dianjurkan sebagai hasil penerapan bagi pihak Safina Assalam Tour adalah sebagai berikut ini.

1. Perlunya perbaikan sisitem dalam pengurusan dokumen sehingga, pengurusan dapat berjalan dengan cepat sesuai dengan perjanjian dengan pelanggan.

2. Penting pengawasan yang ketat sehingga pengurusan dokumen dapat berjalan dengan baik dan cepat.

3. Perusahaan memberikan pelatihan dengan mendatangkan pelatihan khusus keperibadian untuk memberikan tentang pelayanan yang baik dan cara yang benar dalam menghadapi keluhan dari pelanggan secara berkala.

4. Perlunya peningkatan kemampuan para staff dengan mengikuti pelatihan-pelatihan yang diadakan oleh organisasi-organisasi pariwisata sehingga dapat memperbaharui pengetahuan dan kemampuan staff.

\section{DAFTAR PUSTAKA}

Bambang Hariadi, 2003, Strategi Manajemen, Bayumedia Publishing, Jakarta.

David, Fred R., 2012, Strategic Management: Konsep Manajemen Strategis, Salemba Empat, Jakarta.

Hair Joseph F., dkk., 2007, Research Methods for Business, John Wiley \& Sons, West Sussex.

Irawan Handy, 2010, 10 Prinsip Kepuasan Pelanggan, Elex Media Komputindo, Jakarta.
Kotler Philip, 1993, Manajemen Pemasaran: Analisis, Perencanaan, Implementasi, dan Pengendalian, Lembaga Penerbit FEUI, Jakarta.

Kotler Philip, 2005, Manajemen Pemasaran, Lembaga Penerbit FEUI, Jakarta.

Kusmayadi Sugiarto E., 2000. Metode Penelitian dalam Bidang Pariwisata, Gramedia Pusaka Utama, Jakarta.

Malhotra, 2009, Penelitian Populasi dan Sampel, Salemba Empat, Jakarta.

Payne A., 2000. Pamasaran Jasa (The Essence of Service Marketing), Edisi Pertama, Andi, Yogyakarta.

Republik Indonesia, Undang-Undang No. 13 Tahun 2008 tentang Ibadah Haji.

Sugiyono, 2010, Statistika untuk Penelitian, Alfabeta, Bandung.

Supranto J., 2006, Pengukuran Tingkat Kepuasan Pelanggan, Cetakan Ketiga Rineka Cipta, Jakarta.

Tjiptono, 2012, Strategi Pemasaran, Edisi Pertama, Yogyakarta.

Wheelen Thomas L. dan David J. Hunger, 2010 Strategic Management and. Business Policy Achieving Sustainability, Twelfth Edition, Pearson, London.

Zeithmal V., 2003, Marketing Real People. Real Choice, Prentince Hall, New Jersey.

Zeithaml, V. A. dan M.J. Bitner, 1996, Delivering and Performing Service. Part Five. Services Marketing, International Ed., The McGraw-Hill Companies, New York. 